\title{
Moral Ekonomi Perempuan Desa \\ (Studi tentang Resiprositas Budaya dan Disiplin Bisnis \\ Pengrajin Songket di Kecamatan Pemulutan Barat \\ Kabupaten Ogan Ilir)
}

\author{
Lasmiana \\ Dosen STITQ Ittifaqiyah Ogan Ilir \\ llasmiana@gmail.com
}

\begin{abstract}
Abstrak
Penelitian ini difokuskan pada moral ekonomi sebagai hasil dari pertimbangan terhadap situasi resiprositas budaya dengan etika bisnis. Penelitian menggunakan langkah riset deskriptif kualitatif terhadap aspek ekonomi-budaya pengrajin songket pedesaan di Kecamatan Pemulutan Barat kabupaten Ogan Ilir. Dari penelitian ini dihasilkan gambaran bahwa lingkungan pedesaan di Kecamatan Pemulutan Barat memiliki tatanan nilai sosial yang kuat, sehingga berbagai kegiatan termasuk kegiatan yang bersifat ekonomis sangat mempertimbangkan sistem nilai yang berlaku. Pengrajin songket, merasa berkewajiban ikut terlibat baik sekedar hadir menampakkan diri maupun bersikap aktif dalam setiap agenda sosial budaya di pedesaan. Aktivitas ini tentu saja memberikan pengaruh terhadap alokasi waktu untuk kegiatan bisnis mereka sebagai pengrajin baik dalam proses produksi maupun pemasarannya, sehingga mengakibatkan penurunan baik volume produksi, jumlah penjualan, serta hubungan dengan relasi bisnis. Pada umumnya pengrajin songket telah mengetahui, menyadari, dan merelakan penurunan penghasilan, tetapi mereka lebih mengutamakan kebersamaan sebagai warga pedesaan. Dalam keadaan tersebut, secara moral ekonomi pengrajin songket telah melangkah pada ekonomi kapital dengan kategori pra-kapital, sedangkan sebagian masih menjadi bagian dari ekonomi subsistence (cukup memenuhi kebutuhan minimal). Penghasilan dapat ditingkatkan menjadi ekonomi kapital yang lebih maju justru dengan efisiensi pada aspek transportasi dan aspek penguasaan modal berupa bahan, serta peningkatan aspek manajerial. Aktivitas menjaga kebersamaan di pedesaan, serta kegiatan mencari dan meningkatkan perekonomian merupakan tindakan yang membawa kemaslahatan sehingga pada umumnya memiliki kesesuaian dengan nilai Islam. Sementara itu potensi ekonomi kerajinan songket sangat besar. Selanjutnya kegiatan kerajinan songket perlu dikembangkan lebih optimal sehingga menjadi bagian jalan mencapai kesejahteraan yang lebih maksimal.
\end{abstract}

Kata Kunci: resiprositas, disiplin bisnis, moral ekonomi, subsistensi, kapital

\section{Abstract}

This study discusses economic morals as a result of consideration of cultural reciprocity with business ethics. The study used a qualitative descriptive research step on the economic aspects of the culture of rural songket craftsmen in Pemulutan District, Ogan Ilir Regency. From this research, an overview of the environment in the West Pemulutan Sub-district has a strong social value, so that various activities include activities that increase the prevailing system values. Songket craftsmen, participating in participating, both invited to attend, were also invited to be active in every socio-cultural agenda in the countryside. This activity certainly has an influence on the allocation of time for their business activities as craftsmen both in the production and marketing processes, thus increasing production volume, number of sales, and relations with business relations. In general songket craftsmen have understood, pondered, and let down understanding, but they prioritized togetherness as villagers. The economy of songket craftsmen has stepped on the economy of capital with a pre-capital category, while 
some are still part of a subsistence economy (enough to meet minimal needs). Income can be increased to a more advanced capital economy with efficiency in transportation aspects and capital control aspects consisting of materials, as well as improving managerial aspects. Activities to maintain togetherness in the countryside, and activities to seek and improve finance are actions that bring benefits so that they can improve conformity with Islamic values. Meanwhile, the economic potential of songket is very large. Furthermore, songket craft activities need to be developed more optimally so that they become part of the road to achieve greater prosperity.

Keywords: reciprocity, business discipline, economic moral, subsistence, capital

\section{Pendahuluan}

Desa merupakan lingkungan tempat hidup komunitas penduduk yang pada umumnya bekerja sebagai petani, nelayan dan perkebunan. Secara administratif, desa adalah kesatuan masyarakat hukum yang memiliki kewenangan untuk mengatur dan mengurus kepentingan masyarakat setempat berdasarkan asal-usul dan adat istiadat setempat yang diakui dalam sistem Pemerintahan Nasional dan berada di Daerah Kabupaten. (UU No. 22 Tahun 1999). Kehidupan pedesaan, merupakan tatanan masyarakat dan kebudayaan yang memberikan kepada anggotanya adat-istiadat, tata-hubungan sosial yang konkret, yang kemudian diwujudkan dalam suatu pola resiprositas. Dalam pola hubungan resiprositas, tindakan-tindakan yang diperbuat mengandung harapan mengenai kesan dan perilaku orang lain terhadapnya. Suasana ini tidak dapat dilepaskan dari kondisi masyarakat pedesaan yang pada umumnya bersifat relatif homogen serta selalu menjaga kebersamaan. (Soekandar Wiraatmadja, 1978: 132). Kondisi kebersamaan seperti ini pula yang ikut menjadi latar belakang berbagai kegiatan termasuk aktivitas perekonomian.

Secara ekonomi, Boeke menandai masyarakat pedesaan melalui tiga aspek yaitu jiwa sosial (social spirit) yang menggambarkan gaya sosial, bentuk organisasi yang menggambarkan sistem sosial, dan teknik-teknik pendukung yang menunjukkan iklim masyarakat yang bersangkutan. (Boeke, 1982:1). Kondisi ini dapat berpengaruh terhadap aktivitas perekeonomian, khususnya yang diselenggarakan dalam skala mikro seperti yang diselenggarakan sebagai produksi rumah tangga.Aktivitas perekonomian yang bersifat mikro di pedesaan, khususnya di Kecamatan Pemulutan Barat sebagian besar dikelola oleh perempuan (Wawancara Novita Sari, Pegawai Kantor Kecamatan Pemulutan Barat, 2012). Para perempuan berwirausaha dengan gigih dan bersemangat dalam rangka ikut serta meningkatkan perekonomian dan tarap hidup keluarganya, dengan peran yang mereka emban sebagai anggota masyarakat pedesaan tentunya banyak aktivitas lain yang bersifat sosial terkait social spirit dan social system sebagaimana disinggung Boeke terdahulu, juga mau tak mau harus diselesaikan. Salah satu kegiatan wirausaha yang yang diperankan oleh perempuan di Pemulutan Barat yang secara turun temurun dilakukan untuk menopang kehidupan ekonomi, adalah

Tersedia Online di http://jurnal.radenfatah.ac.id/index.php/medinate 
pembuatan songket.

Pekerjaan menenun songket dilakukan bersamaan dengan aktivitas lain yang bersifat sosial dan budaya di desa setempat yang memang memerlukan partisipasi aktif seluruh warganya. Dalam konteks social spirit dan social system di lingkungan masyarakat pedesaan, partisipasi aktif dan keterlibatan dalam aktivitas dan agenda sosial-budaya di pedesaan merupakan tindakan yang penting sebab keterlibatan itu dipandang sebagai bagian dari sikap gotong royong (Wawancara Zakaria, Ketua Lembaga Adat Kecamatan Pemulutan Barat, 2012). Di pedesaan Pemulutan Barat, gotong-royong dan kebersamaan kehidupan masyarakat masih cukup kuat. Hal ini terlihat pada berbagai penyelenggaraan kegiatan terutama upacara yang terkait dengan siklus hidup seperti kelahiran, pernikahan, dan kematian.

Ketiga upacara di atas, di samping beberapa kegiatan lainnya, adalah agenda yang menuntut partisipasi warga yang sekaligus dipandang sebagai penanda kebersamaan dalam masyarakat. Kebersamaan dan sikap gotong-royong seperti ini terkandung dalam istilah caram. Gejala semacam ini kemudian oleh pihak kabupaten diangkat menjadi identitas kabupaten Ogan Ilir. (Wawancara Drs. Muslim Yaroni, pemangku adat Kabupaten Ogan Ilir, 2012). Semangat sosial (social spirit) dan sistem sosial (social system) di lingkungan masyarakat pedesaan seperti di Pemulutan Barat mengikat warganya dalam pola perilaku resiprositas budaya di mana suatu tindakan merupakan peristiwa timbal balik dari tindakan yang lainnya. Dalam pola ini, tindakan seseorang bukan saja diselenggarakan dalam memenuhi kepentingan dan tujuannya sendiri secara pribadi, tetapi tindakan itu terarah pada kepentingan-kepentingan yang bersifat sosial. Nilai seorang individu dalam masyarakat di pedesaan seperti di Ogan Ilir, masih tergantung pada sejauh mana kepedulian dan partisipasinya terhadap orang lain. Lebih luas lagi, apabila seseorang tidak berpartisipasi dalam suatu kegiatan yang bersifat sosial budaya di lingkungan masyarakat setempat, besar kemungkinan ia juga akan kurang didukung bila membuat penyelenggaraan agenda sosial budaya.

Dalam konteks di atas, pengrajin songket berada dalam dua jejaring hubungan sekaligus yaitu dalam konteks perdagangan dengan etika bisnis produksinya dan dalam konteks relasi sosial budaya tempat ia bermukim. Sebagai dua domain yang berbeda, perekonomian dengan kebudayaan memiliki sistem dan tatanan serta tuntutan partisipasi yang berbeda-beda pula. Pengrajin songket, sebagai pelaku ekonomi dituntut untuk mengikuti disiplin yang berlaku di lingkungan bisnis sementara pada sisi lain sebagai warga desa ia terikat dengan adat istiadat setempat. Dalam menghadapi dua tuntutan ini, pengrajin songket memerlukan sikap "bijak" dalam menentukan tindakan mana yang diprioritaskan ketika kedua domain itu sama-sama menuntut jadwal partisipasi. Bagaimana ia mengatasi dilema ini, di sinilah status moral ekonominya sedang dalam ujian. Apakah ia lebih mendahulukan kapitalisasi ekonomi dengan mengabaikan

Tersedia Online di http://jurnal.radenfatah.ac.id/index.php/medinate 
partisipasi terhadap aktivitas sosial budaya ataukah ia lebih mengutamakan aktivitas sosial budaya dengan mengabaikan aktivitas produksinya; ataukah ia memiliki cara lain untuk mengatasi dilemma ini. Pilihan-pilihan ini akan menjadi unsur yang menampilkan status moral keekonomian dari yang bersangkutan.

Sehubungan dengan itu, moral ekonomi secara konseptual adalah "akar-akar normatif yang sangat berpengaruh terhadap dorongan, pertimbangan bersikap, serta makna tindakan ekonomis." (Scott, 1981: 5-6). Nilai moral ini dapat menjadi faktor pertimbangan untuk mempersetujui, menolak, atau menentukan pilihan perilaku dalam berbagai kegiatan, termasuk kegiatan yang bersifat ekonomi dan kebudayaan pada umumnya.

Penelitian ini akan mengangkat aspek moral ekonomi produktif sebagai hasil pertimbangan dari resiprositas budaya dan disiplin bisnis. Sasaran penelitian ini adalah pengrajin songket pedesaan di Kecamatan Pemulutan Barat Kabupaten Ogan Ilir. Menurut catatan pihak kecamatan, jumlah pengrajin songket adalah 1.160 orang (BPS Kabupaten Ogan Ilir, 2011), melibatkan usia yang secara ekonomi bersifat produktif. Penghasilan yang mereka peroleh dipergunakan untuk menopang perekonomian keluarga. Sementara fokus kajian ialah moral ekonomi dalam konteks resiprositas budaya dan disiplin bisnis. Kajian ini diperlukan dalam rangka menjelaskan tentang norma yang melatar-belakangi perilaku ekonomi khususnya pengrajin songket di pedesaan; yang pada akhirnya secara praktis berguna dalam pengembangan ekonomi sekaligus untuk pengembangan aspek sosial budaya masyarakat setempat.

\section{Rumusan Masalah}

Dari latar belakang di atas dirumuskan permasalahan sebagai berikut :

1. Bagaimana kondisi ekonomi, relasi sosial-budaya, serta sistem kerja pengrajin songket di pedesaan dalam kecamatan Pemulutan Barat?

2. Bagaimana resiprositas budaya dan disiplin bisnis pengrajin songket?

3. Bagaimana kondisi moral ekonomi pengrajin Songket dalam kecamatan Pemulutan Barat dikaitkan dengan nilai keislaman.?

\section{Kerangka Teori}

Kajian terhadap moral ekonomi adalah bidang kajian yang memfokuskan pada perekonomian dalam kaitannya dalam konteks nilai-nilai. Bahwa suatu aktivitas ekonomi bukanlah suatu peristiwa yang berlangsung di 'ruang kosong' tetapi berlangsung dalam arena masyarakat dengan kondisi sosial budaya dan nilai tertentu. Kondisi dan nilai ini menjadi latar belakang yang membawa pengaruh terhadap pelaku ekonomi dalam membuat penafsiran, pemahaman, pertimbangan, membuat keputusan,

Tersedia Online di http://jurnal.radenfatah.ac.id/index.php/medinate 
bersikap bertindak, dan sebagainya dalam rangka aktivitas ekonominya.

Kajian terhadap ekonomi dalam kaitannya dengan aspek sosial telah dilakukan oleh Ibnu Khaldun dengan meninjau taraf perkembangan masyarakat dan dinamika ekonominya (Khaldun, 2011:648-657). Dalam kajian Khaldun, perilaku keekonomian sangat dipengaruhi oleh kondisi serta taraf perkembangan masyarakat dan budaya lingkungannya. Perbedaan ini sangat nyata ketika ia membandingkan antara masyarakat perkotaan disertai kebutuhannya yang sangat banyak, berbeda dari masyarakat badui (pedesaan) yang kebutuhannya relatif terbatas; sehingga dapat terpenuhi hanya dengan sedikit pekerjaan. Masyarakat pedesaan tidak terdesak oleh kekayaan (tuntutan kapitalisasi) (Khaldun, 2011: 651).Hal ini nampaknya berlaku pula dengan pengrajin songket pedesaan di wilayah kecamatan Pemulutan Barat. Bahwa, dalam rangka menjalankan aktivitas perekonomiannya, pengrajin ini tidak dapat dilepaskan dari aspek aspek sosial budaya terutama adat-istiadat setempat. Mereka, dalam kesehariannya hidup dalam lingkungan relatif lebih sederhana dari masyarkat perkotaan. Dalam banyak hal, mereka masih belum banyak mengeluarkan biaya karena dapat dilakukan dengan tolong menolong. Sifat tolong menolong ini, menjadi bagian dari nilai penting, yang melekat dalam kehidupan setempat.

Bagaimana nilai ini memberi corak terhadap moral dan tindakan ekonomi para pengrajin songket itu?Secara kebahasaan, "moral" berarti 1. (ajaran) baik buruk yang diterima umum mengenai perbuatan, sikap, kewajiban, dsb.; akhlak; budi pekerti; susila; pengertian ini dapat dijelaskan dalam contoh "moral" mereka sudah bejat, mereka hanya minum-minum dan mabuk-mabuk, bermain judi, dan bermain perempuan. 2. kondisi mental yang membuat orang tetap berani, bersemangat, bergairah, berdisiplin, dsb.; isi hati atau keadaan perasaan sebagaimana terungkap di perbuatan; pengertian ini dapati dijelaskan dalam contoh tentara kita memiliki "moral" dan daya tempur yang tinggi; 3. kesusilaan yang dapat ditarik dari suatu cerita. (Pusat Bahasa Departemen Pendidikan Nasional, Kamus Besar Bahasa Indonesia (Edisi Ke Tiga). (Departemen Pendidikan Nasional, 2003, hlm. 755).

Dalam kajian ini, moral dipahami dalam pengertiannya yang ke dua, yaitu kondisi mental yang membuat orang tetap bersemangat dan berani, sebagaimana dikutip di atas. Secara lebih khusus, dalam konteks perilaku ekonomi, merujuk pada James C. Scott, (Scott, 1981: 5-6) moral ekonomi adalah "pengertian seseorang tentang keadilan serta definisi yang mereka pergunakan tentang eksploitasi”. Moral ekonomi secara konseptual menggambarkan tentang akar-akar normatif yang sangat berpengaruh terhadap dorongan, pertimbangan bersikap, serta makna tindakan ekonomis.Mengembangkan pengertian itu, moral ekonomi dipahami sebagai kondisi mental seseorang tetap berani, bersemangat, bergairah, dan berdisiplin melakukan kegiatan yang bersifat ekonomis. Kegiatan ekonomis, berarti kegiatan yang terkait dengan asas dan proses produksi, distribusi, dan pemakaian barang-barang serta kekayaan. Kegiatan ini mencakupi pula pemanfaatan uang, tenaga, waktu dan sebagainya yang berharga.

Pendekatan moral ekonomi terhadap kegiatan ekonomis masyarakat di pedesaan telah dilakukan oleh Schumacher (Schumacher, 1982:15) dan Scott (Scott, 1986: 20).

Tersedia Online di http://jurnal.radenfatah.ac.id/index.php/medinate 
Para ahli moral ekonomi melihat bahwa hubungan sosial pada komunitas petani disesuaikan untuk menjamin kebutuhan pokok yang minimum. Tuntutan seperti ini menjadikan masyarakat pedesaan senantiasa "berkejaran" antara kebutuhan dan pemenuhannya. Kondisi seperti ini, mendorong lahirnya etika subsisten (subsistence ethic) di mana seseorang melakukan aktivitas ekonomi sebatas pemenuhan kebutuhan pokok.Suasana yang tidak jauh berbeda, digambarkan pula oleh Boeke (Boeke, 1982: 31) yang menyoroti bahwa secara tradisional, bahwa pada bidang pertanian "kerja" bersifat bebas, banyak ragam, banyak segi, dan tidak teratur. Dengan pemahaman dan pengalaman terhadap "kerja" seperti ini, pada umumnya motif bekerja juga tidak terkait dengan pencarian keuntungan untuk kapital, tetapi dilakukan untuk mengatasi kebutuhan minimal kehidupan (subsistence). Semangat ekonomi terjadi dalam keadaan terdesak oleh kebutuhan pokok yang harus dipenuhi. Selanjutnya, bila tujuan mereka telah tercapai, bila mereka telah berhasil memenuhi kebutuhan uang, mereka mulai berhenti bekerja. (Boeke, 1982: 31).

Sementara itu, kajian terhadap kerajinan songket telah dilakukan oleh beberapa pihak secara akademis. Asad Mukti, pada 1985 telah mengajukan penelitiannya terhadap aspek karya dan memfokuskan pada desain motif. Penelitian tersebut dalam rangka penelitian kesenirupaan di Institut Seni Yogyakarta. (Mukti, 1985: 5). Dalam kajiannya didapatkan kesimpulan bahwa desain motif yang diungkapkan melalui berbagai varian motif songket cenderung sangat dipengaruhi oleh konteks lingkungan baik lingkungan alam maupun lingkungan sosial. Bahwa motif-motif itu mencerminkan perhatian masyarakat setempat terhadap tumbuh-tumbuhan seperti pucuk rebung, teratai, dan sebagainya. Kajian akademis lainnya adalah Heri Junaidi, melalui riset disertasi yang dipertahankan di UIN Syarif Hidayatullah. Dalam risetnya itu, Heri Junaidi membahas relasi produktif pada level sesama pelaku ekonomi (Junaidi, 2011: 16). Meski sama-sama melakukan perhatian terhadap aspek keekonomian songket, berbeda degan kajian Heri Juniadi, penelitian ini memfokuskan pada proses produktivitas pengrajin dalam level relasi produksi dan relasi kultural.

\section{Metode Penelitian}

Lokasi penelitian adalah pedesaan di Kecamatan Pemulutan Barat, yang secara administratif meliputi 9 (Sembilan) desa yang mata pencaharian penduduknya mengandalkan pertanian dan perkebunan. Kecamatan ini dipilih karena di seluruh desa terdapat banyak pengrajin songket yang aktif memproduksi songket dengan bekerja di desa setempat maupun menjadi buruh songket di sentra-sentra kerajinan songket kota Palembang. Dengan kenyataan ini, peneliti menganggap lokasi tersebut cukup menarik untuk dijadikan lokasi penelitian terkait tema penelitian.

Penelitian ini adalah penelitian deskriptif kualitatif dengan pendekatan konstruktif-interpretatif. Fokus yang menjadi pokok studi adalah pemahaman tentang proses pembentukan makna dan menerangkan ihwal tentang makna tersebut dalam 
bahasa dan tindakan sosial; dalam kerangka ini dikemukakan pemahaman peneliti tentang konstruksi makna yang diungkapkan oleh aktor yang diteliti (Schwandt, 2009: 146-147), yang dalam hal ini adalah pengrajin songket. Data primer digali dan diperoleh melalui wawancara terhadap aktor pengrajin songket yang tersebar di pedesaan Kecamatan Pemulutan Barat, maupun narasumber lain yang relevan, serta melalui pengamatan langsung terhadap kondisi pengrajin (termasuk perlengkapan, tempat tinggal, lingkungan hidup, dll.) serta aktivitas perdagangan songket. Data primer dalam penelitian ini adalah data tentang moral ekonomi sebagai pertimbangan, sikap dan perilaku pengrajin mengerjakan produksi songket sebagai kegiatan ekonomi dikaitkan dengan partisipasinya terhadap agenda yang bersifat adat-istiadat masyarakat setempat sebagai gejala sosial budaya. Sementara itu, data sekunder adalah data pendukung untuk menjelaskan tentang seluk beluk kerajinan songket sebagai gejala ekonomi pada umumnya serta tentang adat istiadat setempat dalam konteksnya sebagai gejala sosial budaya pedesaan. Data ini diperoleh melalui sumber dokumentasi baik teks maupun grafis seperti terdapat pada dokumen resmi kantor Desa setempat, Sekretariat Kecamatan Pemulutan Barat maupun Kabupaten Ogan Ilir, dan sebagainya. Penelitian ini memanfaatkan pula sumber yang bersifat umum seperti buku teks, Koran, majalah, internet, maupun masmedia pada umumya. Data dikumpulkan melalui observasi, wawancara, dan dokumentasi. Analisis ini diperkuat oleh teknik pengecekan ulang terhadap para narasumber yang terlibat (membercheck) (Lancy, 1993).

\section{Hasil dan Diskusi}

Pemulutan Barat adalah salah satu Kecamatan dalam Kabupaten Ogan Ilir. Kabupaten Ogan Ilir terbentuk melalui Undang-Undang Nomor 37 Tahun 2003 merupakan hasil pemekaran dari Kabupaten Ogan Komering Ilir, secara geografis terletak diantara $2^{0}$ $55^{\prime}$ sampai $3^{0} 15^{\prime}$ LS dan diantara $104^{0} 20^{\prime}$ sampai $104^{0} 48^{\prime}$ BT. Luas wilayahnya $2.666,07 \mathrm{~km}^{2}$ atau 266.607 hektar. Ketika pemekaran, terdapat 6 (enam) kecamatan, yaitu kecamatan Pemulutan, Inderalaya, Tanjung Raja, Tanjung Batu, Muara Kuang, dan Rantau Alai.Dua tahun setelah pemekaran kabupaten menaglami pemekaran menjadi enam belas (16) kecamatan. Peraturan Daerah Kabupaten Ogan Ilir Nomor 22 Tahun 2005 tentang Pembentukan dan Susunan Organisasi kecamatan dalam Kabupaten Ogan Ilir jumlah kecamatan sebanyak 16 kecamatan. Kecamatan Pemulutan Barat, merupakan hasil pemekaran dari Kecamatan Pemulutan.

Kecamatan ini secara geografis terletak di antara $3^{\circ} 02^{\prime}$ sampai $3^{\circ} 48$ Lintang Selatan dan di antara $104^{\circ} 48^{\prime}$ Bujur Timur dengan luas wilayah $60,00 \mathrm{~km}^{2}$ atau 6.000 ha. Adapun batas wilayah administrasi kecamatan Pemulutan Barat, sebelah utara berbatasan dengan Kecamatan Pemulutan, selatan berbatasan dengan Kecamatan Inderalaya, barat berbatasan dengan Kecamatan Inderalaya Utara, dan timur berbatasan dengan Pemulutan Selatan. Ibukota kecamatan adalah Talang Pengeran Ulu, secara administratif rentang wilayahnya terbagi menjadi 11 desa yaitu desa Suka Merindu,

Tersedia Online di http://jurnal.radenfatah.ac.id/index.php/medinate 
Saranglang, Kamal, Pulau Negara, Sri Banding, Talang Pangeran Ulu, Ulak Kembahang I, Ulak Petangisan, Talang Pangeran Ilir, Ulak Kembahang II, dan Arisan Jaya.Sebagian besar desa-desa ini secara administratif telah terbentuk sejak masa sebelum kemerdekaan. Kepadatan penduduk tertinggi di Desa Ulak Kembahang II 358,44 jiwa, sedangkan tingkat kepadatan penduduk terendah di Desa Kamal 120 jiwa. (Tabel 1)

\section{Tabel 1}

Jumlah Penduduk, Pengrajin, dan Luas Wilayah Menurut Desa Di Kecamatan Pemulutan Barat Tahun 2011

\begin{tabular}{|c|c|c|c|c|}
\hline No. & Desa & Luas (KM) & Penduduk & Pengrajin \\
\hline$(1)$ & (2) & (3) & $(4)$ & $(5)$ \\
\hline 1 & Suka Merindu & 4,00 & 1.105 & 113 \\
\hline 2 & Saranglang & 5,00 & 740 & 116 \\
\hline 3 & Kamal & 6,00 & 720 & 113 \\
\hline 4 & Pulau Negara & 7,00 & 1.145 & 41 \\
\hline 5 & Sri Banding & 8.00 & 1.200 & 137 \\
\hline 6 & Talang Pangeran Ulu & 8.00 & 1.945 & 146 \\
\hline 7 & Ulak Kembahang I & 4,75 & 894 & 101 \\
\hline 8 & Ulak Petangisan & 4,00 & 836 & 59 \\
\hline 9 & Talang Pangeran Ilir & 6,00 & 1.668 & 134 \\
\hline 10 & Ulak Kembahang II & 3,85 & 1.380 & 124 \\
\hline 11 & Arisan Jaya & 3,40 & 802 & 76 \\
\hline \multicolumn{2}{|r|}{ Jumlah } & 60,00 & 12.435 & 1160 \\
\hline
\end{tabular}

Sumber: BPS Kabupaten Ogan Ilir, 2011. Katalog BPS 1102001.1610.052:Pemulutan Barat dalam Angka 2010, Inderalaya, Badan Pusat Statistik Kabupaten Ogan Ilir

Industri rumah tangga lain yang secara umum dikembangkn masyarakat adalah pengolahan makanan seperti pembuatan kerupuk kemplang yang terdapat di Ulak Kembahang I, Talang Pangeran Ulu, dan Kamal, serta pembuatan ikan asin di Suka Merindu. Usaha ini dikerjakan secara turun temurun sebagai keterampilan tradisional memanfaatkan hasil alam yang ada di lingkungan sekitar.

Selanjutnya, mata pencaharian penduduk. Mata pencaharian penduduk pada umumnya adalah pada bidang pertanian (termasuk nelayan dan kebun). Aktivitas pertanian, nelayan dan perkebunan, dilakukan secara konvensional, dengan kecakapan dan tradisi yang diwarisi dari generasi ke generasi. Pertanian berupa sawah padi yang menerapkan sistem tadah hujan. Dalam sistem tradisional tadah hujan ini sangat tergantung dengan musim penghujan dan musim kemarau, sehingga masyarakat harus mematuhi jadwal musiman ini kalau tidak mau ladangnya terbengkalai.

\section{Kondisi Perekonomian dan Tradisi}

Pertanian dan kehidupan sebagai nelayan merupakan dua mata pencaharian

Tersedia Online di http://jurnal.radenfatah.ac.id/index.php/medinate 
yang tidak dapat dipisahkan dari masyarakat di Pemulutan Barat. Sebagai masyarakat yang mendiami kawasan dataran rendah dan berawa, kegiatan sawah ladang, mencari ikan, dan berkebun masih dijadikan sebagai mata pencaharian utama. Dalam siklus musiman, kegiatan pertanian dilakukan pada bulan April ketika air mulai surut sampai bulan Agustus ketika datang musim panen pada waktu air kering. Setelah panen padi, datang pula musim buah seperti rambutan, duku, dan berbagai jenis mangga. Pada waktu musim buah sudah berlalu datang pula kegiatan nelayan, yaitu ketika air dalam. Sementara itu, kegiatan peternakan berlangsung sepanjang tahun. Peternakan yang sangat umum adalah ternak unggas dan ternak ikan. Aktivitas lain terkait dengan mata pencaharian masyarkat adalah berupa home industry, yaitu suatu industri rumahan seperti pengolahan bahan makanan, konveksi, dan pembuatan songket.

Para pengrajin songket di wilayah kecamatan Pemulutan Barat, seluruhnya adalah penganut agama Islam. (BPS Ogan Ilir, 2012). Agama ini telah dianut semenjak lahir, secara turun temurun. Pada umumnya pemahaman terhadap agama diperoleh dari lingkungan keluarga, terutama dari orang tua. Selain dari lingkungan keluarga, juga melalui guru mengaji dan dari ustadz yang memberikan ceramah di masjid. Di samping itu, ada yang mendapatkan melalui pendidikan formal, yaitu pendidikan Agama Islam yang terdapat dalam kurikulum di SD, SLTP, dan SLTA. Mereka lahir dan tumbuh di lingkungan pedesaan. Dalam proses pendewasaannya mereka memperoleh pengetahuan, kecakapan, serta keterampilan yang sesuai dengan modalitas tradisi dan sosial serta sesuai pula dengan tuntutan kebutuhan realistis di sosio-kultur di sekitarnya. Keterampilan umum masyarakat pedesaan adalah pada bidang pertanian dan nelayan. Keterampilan yang paling menonjol yang memiliki sifat tradisi dan yang paling diandalkan adalah songket. Kecakapan membuat songket ini diperoleh secara turun temurun sebagai bagian tradisi.

Dalam kerajinan songket, dapat dibagi menjadi tiga macam keterampilan pokok yaitu nyukit, nyongket, dan bedandan.(Uju Tuk, Sesepuh Pengrajin, Saranglang, 2012) Nyukit adalah pembuatan disain awal membuat pola yang akan menentukan motif sebagai subject matter songket yang akan dibuat. Nyongket adalah proses pembuatan tenun kain dengan menyelipkan benang dengan benang yang diselingi benang khusus untuk menampilkan motif yang telah ditentukan, yang diteruskan sampai selesai sebagai produk final. Bedandan ialah keterampilan memperbaiki perlengkapan songket yang rusak atau tidak berfungsi secara benar.

Kemampuan nyukit, ternyata merupakan keterampilan yang paling rumit. Menurut responden, kerumitan ini dialami karena dalam proses nyukit melibatkan kemampuan perhitungan matematis, penalaran logis, dan cita rasa seni yang tinggi. Oleh karena itu orang dengan kapasitas kemampuan nyukit ini adalah langka; Kemampuan nyukit diperoleh dengan belajar khusus kepada ahli nyukit yang sudah ada. Tetapi, menurut beberapa pengrajin, belajar nyukit perlu sabar dan resepan (cerdas). Banyak

Tersedia Online di http://jurnal.radenfatah.ac.id/index.php/medinate 
yang berhenti di tengah jalan karena tidak sabar dalam belajar. (Wawancara Doifa, Pengrajin 2012) Ditemukan dalam penelitian ini, satu sampai tiga orang ahli nyukit di setiap desa.

Selanjutnya kecakapan dan keterampilan bedandan. Dalam istilah lain, bedandan dapat pula disebut sebagai reparasi karena yang dilakukan adalah memperbaiki perlengkapan yang rusak atau tidak berfugsi dengan baik. Selain pengetahuan tentang perlengkapan, sifat bahan, serta proses pembuatan songket, kesabaran dan ketelitian merupakan tuntutan utama dalam kecakapan yang satu ini. Keahlian bedandan diperoleh dengan mengenali secara detil perlengkapan serta fungsifungsinya dalam proses desain awal nyukit, dan proses penenunan waktu nyongket. Oleh karena itu orang dengan keterampilan dan kecakapan ini juga sangat langka. Salah satu di antaranya adalah Marlin (36 tahun) di Desa Talang Pangeran Ulu. Lantaran sangat dibutuhkan, ia serius menekuni profesi khusus mereparasi perlengkapan yang rusak. Kerusakan, pada umumnya terjadi pada suri. Biaya perbaikan suri atau perlengkapan lainnya berkisar sekitar 100 - 150 ribu rupiah, dengan lama penyelesaian sekitar dua hari kerja. (Wawancara Marlin, 2012).

Di samping sebagai aktivitas tradisi, kegiatan bertenun songket, sebenarnya tidak dapat dilepaskan dari aspek lain yang sangat penting yaitu aspek ekonomi. Dalam kaitan ini, songket dipandang sebagai salah satu komoditas yang perlu diperhitungkan dalam proses dan sistem bisnis. Perhitungan ini adalah keharusan, mengingat kenyataan sebagaimana dituturkan para responden bahwa produk songket cukup dapat diandalkan untuk menjadi salah satu penopang perekonomian keluarga. Oleh karena itu, kemampuan lain yang terlibat dalam kerajinan songket adalah kemampuan manajemen dan tata-niaga (khususnya sistem niaga songket). Dalam sistem niaga songket, secara garis besar terlibat beberapa pihak yaitu yang utama adalah pengrajin sebagai tokoh yang memiliki keterampilan pokok untuk produksi, lalu pihak konsumen sebagai pasar hasil produk, dan pemilik modal terutama untuk bahan dasar berupa benang serta untuk perlengkapan pendukung pembuatan songket. Para pengrajin, pada umumnya memiliki keterampilan yang lemah dalam hal manajemen pemasaran dan juga mengalami keadaan yang minim dalam permodalan. Akibatnya, dengan keterampilannya yang sangat terampil itu, dalam sistem tata-naiga songket mereka diperankan dalam posisi sebagai buruh pekerja yang melayani kepentingan pemilik modal (yaitu berupa bahan) yang secara formal dalam tata-niaga ini berperan sebagai konsumen.

\section{Produk dan Kontribusi Ekonomis}

Kerajinan songket sebagai aktivitas produktif merupakan kegiatan ekonomis yang memberikan berbagai keuntungan bukan saja bagi mereka yang terlibat langsung, tetapi juga bagi pihak lain yang tidak terlibat secara langsung. Bahkan secara makro, karena songket merupakan salah satu kecakapan masyarakat setempat, pembuatan dan pengembangan songket merupakan upaya mulia pelestarian kebudayaan lokal. Aspek

Tersedia Online di http://jurnal.radenfatah.ac.id/index.php/medinate 
ekonomis dalam konteks kebudayaan ini, dapat memberikan kontribusi pada industri pariwisata. Wisatawan, baik nusantara maupun mancanegara, selalu mencari sesuatu yang unik dan menarik perhatian terkait dengan kehidupan masyarakat di tempat yang mereka kunjungi.

\section{Posisi Sosial Budaya}

\section{Relasi Sosial}

Pengrajin songket di Pemulutan Barat memiliki posisi sosial yang cukup terhormat, karena mereka tidak menjadi beban ekonomi, bahkan merekalah yang ikut menopang perekonomian di pedesaan. Di lingkungan keluarga, keberadaan mereka sangat berarti walaupun belum dapat disebut sebagai tulang punggung. Penghasilan yang mereka peroleh masih diperhitungkan sebagai penghasilan tambahan, di samping penghasilan utama pertanian dan perikanan. Persepsi ini di lingkungan masyarakat pedesaan di Pemulutan Barat masih berlaku meskipun kenyataannya hasil pertanian dan nelayan semakin menipis. (Wawancara Muhammad Jamin, 2012)

Dalam pandangan masyarakat pada umumnya, terutama generasi tua, dan bahkan para pengrajin songket sendiri, pekerjaan membuat songket bukanlah sesuatu yang diutamakan. Dengan pandangan ini, maka secara tidak langsung, kerajinan songket masih dipandang sebagai pekerjaan sambilan.

Pandangan ini dapat dijelaskan bahwa kerajinan songket itu sendiri adalah keterampilan tradisional, yang menjadi tradisi. Sebagai tradisi, pada masa lalu kerajinan songket tidak dipandang dengan mengutamakan aspek ekonomis, tetapi dijadikan sebagai sarana untuk memperlihatkan keunggulan pribadi para gadis dan perempuan. Para gadis, untuk dapat disebut sebagai seorang perempuan yang siap menjadi dewasa adalah dibuktikan dengan kesempurnaannya dalam membuat songket. Tradisi tentang "pembuktian" ini menjadikan produk akhir songket sebagai suatu karya kerajinan, yang lebih banyak dikaitkan dengan aspek kecakapan sebagai bagian dari keunggulan pribadi. (Wawancara Zakaria, 2012). Oleh karena itu, aspek ekonomi songket pada tahap tertentu masih kurang diperhitungkan.

Pengrajin songket, meski memiliki posisi yang terhormat, bukanlah orang yang istimewa dalam masyarakatnya. Dalam relasi sosial, mereka merupakan warga masyarakat biasa yang terikat dengan norma-norma sebagaimana masyarakat lain pada umumnya. Relasi sosial para pengrajin menjangkau jaringan yang cukup luas dan terbangun melalui berbagai saluran baik yang bersifat primordial seperti karena hubungan kekerabatan, maupun karena faktor fungsional seperti karena kepentingankepentingan seperti kepentingan yang bersifat ekonomis, kepentingan administratif, atau karena hal lain yang melibatkan peran serta mereka.

2. Aktualitas diri dan resiprositas

Lingkungan pedesaan mempunyai ruang sosial-budaya yang sangat luas untuk

Tersedia Online di http://jurnal.radenfatah.ac.id/index.php/medinate 
mengaktualisasikan diri bagi warganya. Banyak peran sosial dan budaya yang dapat dimainkan oleh setiap warga dalam rangka mengaktualisasikan dirinya. Beberapa aktivitas seperti pergaulan sesama warga berlangsung dalam suasana yang cukup akrab dengan frekuensi yang cukup tinggi. Beberapa kegiatan yang menjadi ajang aktualisasi diri seperti pada berbagai acara keluarga terkait siklus hidup seperti berkenaan dengan kelahiran, musibah karena peristiwa kematian, juga terkait peristiwa pernikahan. (Wawancara Zakaria, 2012). Upacara-upacara ini secara tradisi melibatkan seluruh warga desa, dan menjadi semacam kesempatan "berbakti" terhdap sesama warga, terutama terhadap penyelenggara. Pada saat yang bersamaan, partisipasi dalam upacara tersebut merupakan kesempatan untuk menampilkan keberadaan dirinya di antara warga yang lain. Termasuk dalam hal yang ditampilkan itu ialah berbagai keterampilan teknis seperti kepandaian mengupas kelapa, kerapian dalam menghias dekorasi, ketekunan dan kesabaran dalam bekerja, dan sebagainya.

Terkait kelahiran, upacara yang diselenggarakan adalah syukuran sederhana menyambut kehadiran bayi dengan memasak sagon pada hari kelahiran dan pelaksanaan marhaba. Rangkaian kegiatan terkait dengan upacara marhaba telah dimulai sehari sebelumnya yaitu dengan kegiatan bemasak. Pada hari ke dua adalah acara inti, yaitu pelaksanaan marhaba. Upacara lain adalah terkait dengan kematian yaitu takziyah. Takziyah ada yang diselenggarakan selama tujuh hari berturut serta ditambah dengan hari yang ke empat puluh. Ada pula yang menyelenggarakan hari pertama, ke tiga, ke tujuh, dan ke empat puluh. Rangkaian kegiatan ini menuntut partisipasi masyarakat pedesaan berupa kehadiran aktif dalam rangkaian kegiatan, terutama kerabat dekat ahlu musibah.

Sementara itu, aktivitas terkait dengan pernikahan ialah rangkaian upacara seperti mutus rasan, mintak wali, dan acara pernikahan itu sendiri yang masing-masing berlangsung dalam rentang waktu yang cukup lama. Yang paling utama dalam rangkaian upacara ini adalah acara pernikahan (yang biasanya dilanjutkan dengan resepsi). Acara pernikahan dan resepsi disebut sebagai munggah, ini pun diawali dengan kegiatan bemasak pada hari sebelumnya. Di antara berbagai acara yang diselenggarakan terkait dengan siklus hidup, yang paling meriah adalah acara pernikahan. Selain itu, hal yang sama terjadi pula dengan acara sunatan dan khatam Al-Quran.

Demikianlah fenomena yang dikemukakan baik oleh para pengrajin maupun warga pedesaan, tentang partisipasi terhadap kegiatan sosial-budaya dalam masyarakat setempat. Semangat berpartisipasi dalam kegiatan sesame warga, merupakan bagian dari nilai caram yang sampai saat ini masih berlaku di Ogan Ilir. Bahkan, istilah "Caram" telah menjadi bagian dari semboyan kabupaten, yaitu "Caram Seguguk". Dalam makalah "Gotong Royong dalam Adat Caram Seguguk" yang disampaikan pada diskusi Kerukunan Adat Caram Seguguk yang diselenggarakan kabupaten, diperoleh penjelasan (Berlian, 2010:3) bahwa caram adalah bermakna keseragaman.

Tersedia Online di http://jurnal.radenfatah.ac.id/index.php/medinate 
3. Pandangan dan sikap kultur

Dalam penghayatan terhadap nilai caram, warga masyarakat merasa berkewajiban untuk hadir pada rangkaian kegiatan tersebut baik pada hari bemasak maupun pada hari penyelenggaraan marhaba. Rasa wajib untuk hadir dalam rangkaian kegiatan tersebut timbul karena dorongan dari dalam hati nurani sendiri yang merasa tidak pantas kalau tidak hadir. Seluruh responden menyatakan tidak dapat membayangkan untuk secara tidak hadir dalam kegiatgan semacam ini. Bahwa kehadiran dalam setiap acara tersebut merupakan kewajiban, adalah keyakinan yang tidak dapat dirubah. Ada perasaan "tidak enak" yang mengganjal apabila tidak hadir dalam acara tersebut.Para responden tidak dapat menemukan penjelasan yang mereka anggap paling tepat mengenai alasan dan gambaran "tidak enak", kecuali bahwa kalau nanti pada saatnya mengundang khawatir tidak datang. Sehubungan dengan itu, apabila tidak menghadiri acara-acara tersebut, akan dianggap orang sebagai orang yang tidak mau berpartisipasi terhadap sesama warga pedusunan. Pada akhirnya akan dikucilkan.

Terungkap dalam penelitian ini, permasalahan yang muncul dalam peningkatan keuntungan para pengrajin ini adalah justru terbatasnya bahan baku, terutama benang. Dalam hal ini, benang disediakan oleh pembeli tertentu di Palembang, yang sekaligus membeli hasil tenunan dengan harga yang ditetapkan. Apabila benang bukan berasal dari yang bersangkutan, maka harganya akan sangat murah. Ini menjadikan mereka terikat dengan oknum tertentu di pasar melalui penjualan bahan terutama benang.

Di samping motif kapital, sebagian kecil pengrajin songket memiliki motif ekonomi resisten. Mereka cukup puas dengan kondisi apa adanya, dan dalam hal ini mereka melihat aspek komersial songket didorong oleh upaya untuk memenuhi kebutuhan sehari-hari. Apabila uang di tangan mulai menipis, pengerjaan songket dilakukan dengan bersemangat tinggi. Tidak jarang, songket dikerjakan siang malam agar cepat selesai dan segera dijual untuk memenuhi kebutuhan itu. tidak sedikit pula yang melakukan 'ijon'. Akan tetapi apabila kebutuhan telah terpenuhi, pengerjaan kembali dilakukan dengan mengulur-ulur waktu. Bagi kelompok ini, tidak peduli apakah mendapat keuntungan besar atau kecil, yang penting ada uang untuk memenuhi kebutuhan yang mendesak.

\section{Praktek Bisnis Pengrajin}

Proses pembuatan songket, dimulai dari pembuatan pola motif awal melalui nyukit. Nyukit yaitu membuat desain motif dan corak tertentu yang selanjutnya akan diturunkan dalam proses penyusunan benang sampai terjadi sehelai songket. Setelah mendapatkan motif melalui nyukit, dilanjutkan dengan proses penyusunan benang satupersatu sampai menjadi sehelai kain ataupun sehelai kemban (selendang). Setelah finishing touch, songket sudah siap untuk dipasarkan. Akan tetapi, masih belum siap untuk dipakai karena untuk siap pakai masih perlu diberi puring. Puring merupakan

Tersedia Online di http://jurnal.radenfatah.ac.id/index.php/medinate 
kain tambahan yang dimaksudkan mempermudah pemakaian dengan cara mengikat menggunakan setagen ataupun alat lain untuk mengikatkan songket pada badan.

Tahap-tahap yang dilalui penyusunan benang sampai menjadi kain memerlukan waktu sekitar sepuluh hari kerja. Apabila hendak mempergunakan kembali motif yang sama, maka tinggal melakukan penyambungan benang. Selanjutnya diteruskan dengan proses penyusunan benang sampai selesai. Akan tetapi, apabila menghendaki motif yang lain, maka perlu proses nyukit untuk desain dengan motif dan corak yang baru. Tidak semua pengrajin dapat membuat motif dan corak dengan nyukit ini. Diperlukan keterampilan, penalaran logis, kesabaran, serta ketelitian yang akurat dalam membuat desain melalui nyukit. Biasanya, untuk nyukit diserahkan pada pengrajin yang dipandang ahli nyukit. Biaya jasa nyukit, berkisar 400-500 ribu rupiah untuk satu set motif dan corak.

Seperti telah disinggung terdahulu, tata-niaga songket yang berlangsung di kalangan pengrajin songket Pemulutan Barat melibatkan pihak yang berperan sebagai pemilik modal, pasar, dan pekerja produksi. Dalam konteks ini, terdapat beberapa mekanisme, (Wawancara Beti, 2012) yaitu:

a. Pengrajin berperan sebagai pekerja produksi dan sebagai pemilik modal. Pengrajin dengan kategori ini mencakupi mereka yang mempunyai alat perlengkapan sendiri, memiliki bahan sendiri yang secara bebas dibeli di pasar (tanpa ada ketentuan beli kepada siapa, dan di mana). Mereka yang berada dalam kategori ini juga memiliki kebebasan untuk menjual hasil kerjanya kepada siapa saja, di mana saja, dan dengan harga yang ditetapkannya sendiri yang dianggap membawa keuntungan. Mereka ini cenderung sangat merdeka dalam menentukan jadwal penyelesaian songket.

b. Pengrajin yang tidak mempunyai modal bahan, tetapi mempunyai modal dayan (alat produksi songket) dan kecakapan. Pengrajin dalam kategori ini tetap dapat melakukan proses produksi dengan 'meminjam' benang kepada pemilik modal (kapitalis). Mereka dalam kategori ini, bila telah menyelesaikan kerja berupa menghasilkan produksi songket, tidak memiliki kebebasan karena terikat pada 'keharusan' untuk menjual kepada kapitalis yang telah meminjamkan benang terdahulu.

Si pengrajin dalam kategori ini tidak pula memiliki keleluasaan lagi untuk menetapkan harga songket yang dijualnya. Dengan posisi seperti ini secara otomatis pengrajin sangat terikat dan tidak dapat mencari harga yang lebih menguntungkan. Mau tak mau menerima adanya. Kategori ini berlaku pula terhadap pengrajin yang terjebak dalam praktek ijon.

c. Pengrajin semata-mata dalam posisi memburuh baik dengan modal serta alat produksi pinjaman maupun modal pinjaman dan alat produksi sendiri. Mereka ini sejak awal mengerjakan pembuatan songket dengan konpensasi upah berkisar sebesar 500.000,rupiah untuk penyelesaian satu set (kain dan selendang). Pengrajin dalam kategori ini 
tentu tidak pernah bersentuhan langsung dengan pasar, baik sebagai pembeli benang maupun sebagai penjual. Kerapian hasil dan disiplin terhadap jadwal merupakan acuan pokok bagi mereka yang bertahan dalam posisi ini.

Tiga kategori di atas, secara bervariasi merupakan kegiatan produksi yang membuahkan hasil berbeda-beda pula. Beberapa peluang kelemahan dalam sistem di atas adalah bahwa dalam kategori pertama, yaitu pengrajin dengan modal sendiri dan menjual sendiri adalah pengaturan jadwal produksi. Dalam konteks keekonomian, mereka ini berproduksi bukan untuk tujuan peningkatan capital, tetapi sekedar untuk memenuhi tuntutan kebutuhan ekonomis yang bersifat resistensi. Dalam keadaan ini, apabila ditangannya masih tersedia uang untuk memenuhi keperluan hidup, mereka bersikap santai. Tetapi setelah persediaan dana sudah habis, dan kebutuhan mendesak, mereka dengan bergegas menyelesaikan produksi songket sehingga dengan segera dapat dijual di pasar. Selanjutnya, setelah terjual, dan setelah dana yang ditangan dirasakan masih ada, kembali mereka bekerja dengan tanpa ketentuan jadwal.

Dalam kategori ke dua, pengrajin mendapatkan bahan benang tenunannya agar bisa atau tetap bisa menenun peluang kelemahan adalah ketika pengrajin menjual hasil tenunan. Kelemahan bagi pengrajin tanpa modal artinya pinjam benang dengan produsen, pengrajin tidak bisa menjual hasil tenunanya dengan bebas untuk mencari harga yang lebih tinggi, karena kemufakatan hasil tenunannya harus dikembalikan kepada yang memberikan pinjaman benang yang secara otomatis tetap saja terjual. Dan biasanya juga yang biberikan pinjaman benang bagi pengrajin yang jujur, dan tenunannya rapi dan padat. Bagi para pengrajin yang mempunyai modal sendiri dia terbatas dengan kembang dayan (motif) yang dipunyai. Keterbatasan ini karena mereka memang tidak dapat nyukit (membuat pola awal disain) sendiri. Lagi pula, terkadang terjadi semacam monopsoni (penguasaan pasar oleh sekelompok orang). Hal ini terjadi mendapatkan hambatan waktu mau menjual hasil tenunannya, yaitu pengrajin sangat sulit disamping bebas mencari pembeli biasanya para pembeli (toke) tidak mudah memutuskan begitu saja untuk membeli dengan alasan tidak ada ikatan, akhirnya kadang-kadang hasil tenunannya dibeli oleh konsumen yang tadinya berperan sebagai pemilik modal (penjual benang).

Pasar songket, sebagai jaringan yang dimiliki secara tetap dalam memasarkan hasil tenunannya selama ini hanya ke pasar 16 ilir Palembang dan di kawasan Ramayana kompleks Ilir Barat Permai. Untuk yang disebutkan terakhir, dapat dikatakan baru sebatas pengrajin tertentu digolongkan masih sangat terbatas terutama yang bisa dijual dipasar ini bagi yang hasil tenunannya betul-betul rapi dan padat. Selanjutnya, bagi pengrajin yang berperan sebagai buruh upahan, adalah sangat tergantung pada ketepatan waktu, kerapian, dan ketelitian. Apabila beberapa kali

Tersedia Online di http://jurnal.radenfatah.ac.id/index.php/medinate 
'meleset', mereka cenderung mendapat nilai negatif. Para pengrajin yang bekerja memproduksi di beberapa perusahaan di sentra songket Tangga Buntung Palembang, banyak yang berasal dari Pemulutan Barat. Bahkan, Zainal Songket, secara khusus pernah mendirikan cabang kegiatannya di desa Kamal kecamatan Pemulutan Barat.

Dari sekian banyak pengrajin yang telah menekuni kerajinan songket secara turun temurun, peneliti menemukan hanya beberapa orang yang telah mempunyai krakter bisnis yang berjaringan. Mereka ini mengolah dan memasarkan hasil tenunannya dengan menggunakan jaringan di luar pasar 16 Ilir dan pasar Ilir Barat Permai. Beberapa pengrajin yang masih menetap di Pemulutan Barat, dan satu pengrajin lagi memilih hijrah ke Palembang. Mereka ini menjajagi pasar berupa individu dan relasi yang bersifat pribadi.

Selanjutnya, dari sisi ekonomi, songket merupakan hasil karya yang memiliki nilai ekonomis. Secara potensial, dapat dikalkulasikan bahwa rata-rata pendapatan satu stel kain songket bisa mencapai Rp. 600.000,- (wawancara Dian, 2012). Dengan waktu rata-rata lama pembuatan 10 hari kerja. Artinya kalau dalam periode waktu selama satu bulan katakanlah pengrajin itu mampu menyelesaikan dua setel kain songket jadi mereka mendapatkan uang sebesar Rp. 1.200.000,- Penghasilan ini telah mencapai UMR. Apalagi kebanyakan pengrajin dalam satu keluarga rata-rata tidak satu orang, bahkan bisa 3 orang. Dengan personil yang lebih dari satu orang tentunya akan lebih besar pula pendapatan dalam satu keluarga. Akan tetapi, karena kekurangan modal produksi, juga kurangnya penataan manajemen, potensi ini belum berhasil maksimal.

Keterampilan yang dimiliki pengrajin dapat dijadikan sebagai jatidiri wilayah dan peninggalan secara turun temurun yang patut diangkat dan dilestarikan sebagai budaya tempat pariwisata sebagai sentra produksi kerajinan pada ahirnya bisa mengangkat perekonomian daerah. Adanya aktivitas kerajinan songket, jelas memberikan kontribusi secara terhadap perekonomian keluarga dan terhadap perekonomian desa. Dalam perhitungan kasar, seorang pengrajin songket dapat menghasilkan pendapatan minimal 1.800.000,- rupiah selama sebulan, sementara di sembilan desa di kecamatan Pemulutan Barat rata-rata terdapat minimal 600 orang pengrajin songket aktif, maka dalam satu bulan di pedesaan dalam Kecamatan Pemulutan Barat beredar uang sebesar adalah 1.080.000.000,- (Satu Milyar Delapan Puluh Juta) rupiah. Angka minimal ini masih dapat meningkat, dengan menambahkan penghasilan jasa cukit dan jasa reparasi perlengkapan songket. Jumlah ini cukup besar bila diorganisir dalam konteks dinamika perekonomian pedesaan. Pengorganisasian ini, dilakukan dengan mempertimbangkan pula akses dan ketersediaan bahan baku secara lebih terbuka dan lebih bebas.

\section{Analisis Keislaman}

Tersedia Online di http://jurnal.radenfatah.ac.id/index.php/medinate 
Aktivitas perekonomian di pedesaan, secara keislaman dapat dipandang sebagai kegiatan umat dalam rangka mencari rezeki Allah yang ditebarkan di muka bumi. Aktivitas ini, dalam konteks syariah dapat dikategorikan sebagai kegiatan mu amalah. Dikatakan demikian karena peristiwa perdagangan atau bisnis songket merupakan bagian dari pergaulan antar sesama manusia. Dalam pergaulan ini baik penjual maupun pembeli sama-sama bersandar pada akad khusus maupun norma-norma umum perdagangan yang berlaku di kalangan pedagang dan pengrajn songket.

Pengrajin songket di Pemulutan Barat pada umumnya adalah muslim, dan memiliki tingkat pengetahuan serta konsistensi terhadap ajaran Islam secara bervariasi. Tetapi ditinjau dari tingkat pendidikan formal baik sekolah khusus keislaman maupun sekolah umum, mereka memiliki tingkat pendidikan yang rendah. Pengetahuan dan praktek keislaman dipelajari dari orang tua, guru mengaji desa, melalui penceramah yang datang ke masjid maupun yang mereka pantau melalui media penyiaran radio dan televisi. Reverensi berupa text-book yang mereka jadikan acuan adalah buku-buku yang bersifat tuntunan praktis peribadatan sehari-hari. Dengan kondisi seperti ini, para pengrajin songket ini dikategorikan sebagai "awam" terhadap kajian tentang ekonomi Islam. Jadi aplikasi keislaman yang mereka selenggarakan dalam kehidupan adalah aplikasi sebatas kemampuan masyarakat awam. Apa yang mereka anggap sebagai benar atau salah, Islami atau tidak berdasarkan kebiasaan yang berlaku dan mereka persepsikan sebagai suatu yang baik. Tuntunan tersebut baik memang bersumber langsung dari khazanah keislaman (seperti pengajian, buku-buku keagamaan, ustaz, dan sebagainya) juga dari adat istiadat setempat.

Pembuatan songket itu sendiri pada mulanya merupakan bagian dari kegiatan yang telah tersedia dalam tradisi setempat. Ketika pengrajin ini lahir, mereka telah mendapati masyarakat setempat telah melakukan pembuatan songket. Dalam hal ini, sebagai suatu unsur tradisi (urf), produk kebudayaan seperti songket, dapat dipandang sebagai suatu hal yang mubah (boleh). Pemahaman dan sikap bahwa kebudayaan merupakan suatu yang mubah antara lain diperoleh dari salah satu rumusan Sidang Tanwir Muhammadiyah di Surakarta (PP Muhammadiyah, 1994). Bila ditelusuri lebih jauh, sebenarnya produk jenis songket ini termasuk dalam kategori produk tenun yang telah dikenal dalam lingkungan Islam (Khaldun, 2011: 684, 685). Sebagai produk yang diperlukan, tentu songket memiliki nilai ekonomis dan dijadikan sebagai bagian dari upaya yang bersifat keekonomian sehingga bisnis songket merupakan suatu yang lumrah. Menjadikan songket sebagai obyek bisnis dalam tinjauan syariat Islam adalah suatu yang mubah, bahkan karena dapat meningkatkan kapasitas perekonomian, bisnis songket dapat berpotensi sebagai kegiatan yang mengandung kemaslahatan sehingga secara prinsip aktivitas ini perlu didorong semaksimal mungkin.

Pada sisi lain, pengrajin songket sebagai warga masyarakat, adalah individu

Tersedia Online di http://jurnal.radenfatah.ac.id/index.php/medinate 
yang tidak terlepas dari norma "resiprositas" budaya setempat. Keaktifan dalam kegiatan masyarakat, perlu dipandang sebagai bagian dari menjaga kebersamaan dan bentuk pelestarian silatu rahîm sesama umat. Oleh karena itu respons terhadap resiprositas merupakan sesuatu yang sangat diperlukan.

Dari paparan di atas, terlihat bahwa dua bidang kegiatan yang dilakukan oleh pengrajin yaitu kegiatan produksi songket dan kegiatan dalam relasi sosial budaya pedesaan, adalah sama-sama mengandung kebaikan yang bersifat kemaslahatan. Kemaslahatan pada kegiatan produksi membawa keuntungan pada peningkatan hasil dan kapital yang bersifat material. Sementara kemaslahatan pada bidang relasi sosial budaya membawa keberuntungan, sebagai reward, berupa pengukuhan dan penguatan diri dalam sistem relasional sosial budaya setempat. Sebaliknya, kemaslahatan tersebut, bila ditinggalkan sama-sama mengandung risiko tersendiri. Dalam hal ini, risiko pada bidang produksi songket akan muncul berupa pengurangan jumlah hasil produksi yang kemudian berakibat pada pengurangan keuntungan material. Sementara itu risiko meninggalkan pencapaian kemaslahatan pada bidang relasi sosial budaya akan melahirkan risiko berupa gangguan relasi sosial budaya seperti perasaan tidak enak, malu, khawatir tidak mendapat respek, dan sebagainya yang pada umumnya menggambarkan keterkucilan diri.

Untuk menyelaraskan dua bidang yang sama-sama membutuhkan alokasi waktu di atas, yaitu antara aktivitas bisnis dengan respon terhadap resiprositas budaya, diperlukan manajemen yang selaras. Penyelarasan ini tentu merupakan suatu yang rumit, tetapi sebagaimana diungkapkan pengrajin, selama ini penyelarasan yang telah telah dilakukan adalah dengan cara:

1. Dalam relasi pengrajin dengan pihak pasar, khususnya dalam akad bisnis songket, dilakukan dengan sistem jual lepas, sehingga tidak ada ikatan waktu. Akan tetapi dalam jual lepas ini mereka sering terikat dengan 'monopoli pasar' oleh pihak konsumen yang berakibat pada pembatasan harga. Hal ini terjadi karena terkait keterbatasan pengadaan bahan (benang). Sementara terhadap kualitas produk, dilakukan pengecekan bersama penjual dan pembeli.

2. Terhadap resiprositas budaya, terutama dalam konteks menghadiri kegiatan tradisi sosial budaya, para pengrajin selaku warga desa selalu bersikap aktif. Dalam keadaan dilematis, mereka menempatkan tradisi sosial budaya sebagai prioritas baru kemudian produksi songket; tetapi dalam keadaan sangat mendesak, dua kegiatan dilakukan dengan cara "berbagi". Cara ini sangat efektif bagi pengrajin yang telah mempunyai pasangan hidup, di mana perempuan hadir pada upacara siang, laki-laki hadir pada kegiatan di malam hari.

Solusi di atas selama ini dipergunakan dalam manajemen mengatur kesibukan bisnis songket dan relasi sosial budaya di pedesaan, yang menurut pengrajin dirasakan

Tersedia Online di http://jurnal.radenfatah.ac.id/index.php/medinate 
cukup efektif. Bagaimanapun juga, tentu masih diperlukan siasat lain yang lebih sempurna dalam rangka meningkatkan produktivitas bisnis pada satu sisi, sekaligus memperkuat ikatan sosial budaya pada sisi lain.

Di atas semua itu, pada akhirnya apabila tuntutan dua bidang itu mengharuskan dipilih salah satu, pada umumnya para pengrajin memilih mengutamakan kemaslahatan dalam bidang relasi sosial. Pilihan ini memperlihatkan bahwa para pengrajin ini pada prinsipnya sudah masuk dalam kategori kapital, tetapi masih belum mencari-cari pola manajemen yang tepat sehingga dapat berlangsung sesuai dengan konteks sosial budaya setempat. Kondisi tersebut memperlihatkan gambaran bahwa moral ekonomi pengrajin songket di pedesaan Pemulutan Barat ini dapat dikategorikan pada tahap pra-kapital.

Sementara itu, sebagai muslimah, pada umumnya pengrajin itu belum memahami tentang batasan nisab untuk berzakat terhadap penghasilannya memproduksi songket sehingga mereka mengaku belum mengeluarkan zakat penghasilan secara tepat. Yang mereka lakukan selama ini pada umumnya adalah mengeluarkan zakat fitrah pada setiap hari hari raya Idul Fitri. Pengeluaran lain yang mereka kaitkan dengan keagamaan ialah sumbangan dan mengisi kotak amal di masjid, ataupun untuk persatuan amal kematian.

\section{KESIMPULAN}

Dari paparan pada bagian terdahulu tentang moral ekonomi pengrajin songket di Kecamatan Pemulutan Barat, dapat digarisbawahi bahwa: Seperti umumnya masyarakat pedesaan di Kecamatan Pemulutan Barat, basis ekonomi Pengrajin songket di pedesaan Kecamatan Pemulutan Barat pada umumnya adalah pertanian, nelayan, serta perkebunan; dan mereka menjadikan produksi songket sebagai pendapatan tambahan; dalam berproduksi mereka menerapkan sistem kerja dalam bentuk produksi rumah tangga. Kendala utama produksi mereka adalah rendahnya kualitas, kepemilikan modal untuk pengembangan menjadi industri kapital yang lebih besar.

Relasi sosial budaya mereka sangat luas, melampaui batas wilayah di Pemulutan Barat saja; Sebagai warga yang terikat pada sistem nilai, pengrajin songket berperan aktif dalam resiprositas sosial budaya setempat; sehingga aktivitas bisnis dilakukan bersamaan dengan aktivitas sosio-kultur setempat. Dalam melakukan bisnis pada umumnya mereka memiliki pasar yang relatif tetap, dengan sistem jual lepas sehingga membebaskan jadwal dan volume produksi. Tetapi dalam hal tertentu para pengrajin masih terikat, karena bahan produksi pada umumnya berasal dari pihak pembeli.

Para pengrajin pada umumnya lebih cenderung pada ciri moral ekonomi kapitalis dengan kategori ekonomi pra-kapital dan ada sebagian kecil subsisten. Usaha kerajinan songket ini dilakukan bersamaan dengan kegiatan memperkuat kebersamaan sebagai salah satu basis masyarakat di pedesaan pada umumnya. Secara keislaman, fenomena sebagaimana ditemukan pada pengrajin songket di Pemulutan Barat,

Tersedia Online di http://jurnal.radenfatah.ac.id/index.php/medinate 
merupakan gejala positif karena di dalamnya terkandung unsur kemaslahatan.

\section{DAFTAR PUSTAKA}

\section{Al-Quran al-Karîm}

Azzam, Prof. Dr. Abdul Aziz Muhammad Azzam, 2010. Fiqh Muamalat: Sistem Transaksi dalam Fiqh Islam (a.b.: Nadirsyah Hawari, Lc., MA.), Jakarta, Pustaka Amzah

Azra, Azyumardi. 1994 Jaringan Ulama Timur Tengah dan kepulauan Nusantara abad XVII dan XVIII : akar pembaruan Islam Indonesia, Bandung, Mizan

Berlian, Saudi, 2007. Sejarah Masyarakat dan Pemerintahan Ogan Ilir, Inderalaya, Pemerintah Kabupaten Ogan Ilir

----------------, 2010 “Gotong Royong dalam Adat Caram Seguguk”, disampaikan pada Diskusi dan Orientasi Pengurus Masyarakat Kerukunan Adat Caram Seguguk Ogan Ilir, Inderalaya, 5 Juli 2010

Boeke, 1982.“Memperkenalkan Teori Ekonomi Ganda”, dalam Sajogyo, Bunga Rampai Ekonomi Desa, YOI-IPB

Buchori, Sidi Ibrahim, 1971.Sejarah Masuknya Islam di Indonesia, Jakarta, Publicita,

Coleman, James S.,2010.Dasar-Dasar Teori Sosial, (a.b.: Imam Muttaqien, Deta Sri Widowatie, Siwi Purwandari) Bandung, Nusa Media

Evers, Hans-Dieter, Wolfgang Clauss, dan Diana Wong, 1988."Rerproduksi Subsistensi, Suatu Kerangka Analisis", dalam Teori Masyarakat: Proses Peradaban dalam Sistem Dunia Modern. Jakarta, Yayasan Obor Indonesia

Goodman, Douglas J, dan George Ritzer, 2011. Teori Sosiologi, Yogyakarta, Kreasi Wacana

Haryanto, Drs. Sindung, 2011.Sosiologi Ekonomi, Yogyakarta, Ar-Ruz Media

Hayami, Yujio dan Masao Kikuchi,1978.Dilema Ekonomi Desa, Jakarta, Yayasan Obor Indonesia

Hitti, Philip K., 2006. History of Arabs: Rujukan Induk dan Paling Otoritatif tentang Sejarah Peradaban Islam,(a.b.: Cecep Lukman Yasin dan Dedi Slamet Riyadi), Jakarta, PT. Serambi Ilmu Semesta

Homans, George C., 1950. The Human Group, New York: Harcourt, Brace and Company

Husaini, Dr. S. Waqar Ahmad, 1983. Sistem Pembinaan Masyarakat Islam, Bandung, Pustaka

Tersedia Online di http://jurnal.radenfatah.ac.id/index.php/medinate 
Junaidi, Heri, Dr. M.A., 2011. Efisiensi Berkeadilan: Pilar Pemberdayaan Ekonomi Kerakyatan Berbasis Syariah, Palembang, Rafah Press

Khaldun, Ibnu, 1987.Muqaddimah (a.b.: Ahmadie Thaha), Jakarta, Pustaka Firdaus ,2001.Mukaddimah (a.b.: Masturi Irham, Lc., Malik Supar, Lc., dan Abidun Zuhri), Jakarta, Pustaka Al-Kautsar

Kitab Oendang-Oendang Simboer Tjahaja, 1939. Hasil Rapat Kepala Anak-Anak Negeri Karesidenan Palembang, 2-6 September 1927, Palembang, Meroe Boekhandel en Drukkerij

Lancy, D.F. 1993. Qualitatif Research in Education: An Introduction to Major Traditions. New York \& London: Longman

Leur, JC. Van.,1974.Indonesian Trade and Society: Essay in Asia Social and Economic, Houston: The Hague; Bandung, W. van Hoeve

Mauss, Marce1,1992. Pemberian: Bentuk dan Fungsi Pertukaran dalam Masyarakat Kuno, (a.b.: Parsudi Suparlan), Jakarta, Yayasan Obor Indonesia

Mukti, Asad, 1985. Motif Songket Palembang, Skripsi Fakultas Seni Rupa dan Desain Institut Seni Indonesia, Yogyakarta

McClelland, D. C., 1985. Human Motivation, Illinois, Scott, Foresman \& Company

Muhammad,2002.Etika Bisnis Islami, Yogyakarta, Unit Penerbitan AMP YKPN

Pelly, Usman, 1996 . "Agama dalam Etos Kerja Rakyat di Sumatera”, dalam Ruh Islam dalam Budaya Bangsa, Jakarta, Yayasan Festival Istiqlal

Pimpinan Pusat Muhammadiyah, 1994. Keputusan Sidang Tanwir Muhammadiyah di Surakarta 31 Desember 1994, Yogyakarta, PP Muhammadiyah

Polanyi, Karl, C.M. Arensberg, dan H.W. Pearson, 1988. "Ekonomi sebagai Proses Sosial," dalam Teori Masyarakat: Proses Peradaban dalam Sistem Dunia Modern. Jakarta, Yayasan Obor Indonesia

Polyani, Karl,1957.The Human Live, New York, Akademic

Proyek IDKD Depdikbud Sumatera Selatan, 1994. Pengrajin Tradisional di Daerah Sumatera Selatan, Palembang

Pusat Pengkajian dan Pengembangan Ekonomi Islam (P3EI) Universitas Islam Indonesia Yogyakarta -BI, 2008. Ekonomi Islam, P3EI UII

Qardhawi, Dr. Yusuf, 2009. Fatwa-Fatwa Kontemporer, (a.b.: Moh. Suri Sudahri, dkk.), Jakarta, Pustaka Al-Kautsar

Qorie, KH. Moersjied, Muslih Qorie dan Mudrik Qorie,1996. Nuansa Seni Marhaban, Inderalaya, Al-Ittifaqiah

Rodinson, Maxim,1982. Islam dan Kapitalisme, (a.b.: Asep Hikmat)Bandung, Iqra

Romli, Drs. M.Ag., 2006. Ushul Figh: Metode Penetapan Hukum Islam (Jilid 1), Palembang, IAIN Raden Fatah Press

Tersedia Online di http://jurnal.radenfatah.ac.id/index.php/medinate 
Rus`an, H., 1992. RingkasanIhya Ulumiddin - Al Ghazali, Semarang, Penerbit Wicaksana

Santosa, Ippho dan Adalus - Khalifah, 2010. Muhammad sebagai Pedagang, Jakarta, Elexmedia Computindo

Sajogyo, 1982. Bunga Rampai Perekonomian Desa, Jakarta, Yayasan Obor Indonesia

Scott, James C.,1986. Moral Ekonomi Petani: Pergolakan dan Subsistensi di Asia Tenggara (a.b.: Hasan Basari), Jakarta, LP3ES

Scott, John, 2011. Sosiologi: The Key Concept, (a.b.: Labsos Fisip Unsoed), Jakarta, Raja Grafindo Persada

Schumacher, F., 1982. Kecil Itu Indah, Jakarta, LP3ES

Subhani, Ja`far,2004.Ar-Risalah: Sejarah Kehidupan Rasulullah s.a.w., (a.b.: Muhammad Hasyim dan Meth Kieraha), Jakarta

Suyadi MP, Drs., 1985. Buku Materi Pokok Ilmu Budaya Dasa, Jakarta, Depdikbud-UT

Syarifuddin, Prof. Dr. H. Amir, 2009. Ushul Fiqh (2 jilid), Jakarta, Kencana

Turner, Bryan S., Nicholas Abercrombie, Stephen Hill,2010. Kamus Sosiologi, Yogyakarta, Pustaka Pelajar

Weber, Max,2001.Etika Protestan dan Semangat Kapitalisme, (a.b.: Yusup Priasudiarja), Surabaya, Pustaka Promethea

Wiraatmadja, Soekandar, M.A.,1978. Pokok-Pokok Sosiologi Pedesaan, Jakarta, Yasaguna

\section{Bahan Arsip}

Bappeda Kabupaten Ogan Ilir,2012.Profil Kabupaten Ogan Ilir, Inderalaya, Bappeda Kabupaten Ogan Ilir , Peta Kabupaten Ogan Ilir, Bappeda Kabupaten Ogan Ilir, 2012 , Peta Kecamatan Pemulutan Barat Kabupaten Ogan Ilir, Bappeda Kabupaten Ogan Ilir, 2012.

Biro Pusat Statistik Kabupaten Ogan Ilir, Kecamatan Pemulutan Barat Dalam Angka, BPS Ogan Ilir, Inderalaya, 2011. , Ogan Ilir dalam Angka, BPS Ogan Ilir, Inderalaya, 2012.

Sekretariat Badan Pusat Statistik Ogan Ilir,2011.Pemulutan Barat dalam Angka 2010, BPS Kabupaten Ogan Ilir

Sekretariat Daerah Tingkat I Sumatera Selatan, 1983. Surat Keputusan Gubernur Kepala Daerah Tingkat I Sumatera Selatan Nomor 142/KPTS/III/1983 Tentang Penghapusan Pemerintahan Marga, Pemberhentian Pasirah Kepala Marga, Ketua/Anggota DPR Marga dan Pejabat Pamong Marga Lainnya

Tersedia Online di http://jurnal.radenfatah.ac.id/index.php/medinate 
Serta Penunjukan Pejabat Kepala Desa Dalam Wilayah Propinsi Daerah Tingkat I Sumatera Selatan., Palembang, Setda. TK. I Sumatera Selatan

Sekretariat Desa Saranglang, 2011.Foto-foto aktivitas Khatam Al-Quran di desa Saranglang, Saranglang.

Sekretariat Kecamatan Pemulutan Barat,2011.Data Umum PKK, Talang Pangeran, Sekretariat Kecamatan Pemulutan Barat , 2011.Data Kegiatan TP PKK Kecamatan Pemulutan Barat, Talang Pangeran, Sekretariat Kecamatan Pemulutan Barat

Sekretariat Negara RI, 1979. Undang-Undang No. 5 Tahun 1979 tentang Pokok-Pokok Pemerintahan Desa, Jakarta, Setneg. RI 